\title{
Korea's National Interests and Security Conditions in the Age of Globalization
}

\author{
Ihn-hwi Park \\ (Ewha Womans University)
}

$\langle$ CONTENTS〉

I . Introduction

II . Globalization and Korea's Changing Security Environment

1. Globalization and Security

2. Changes in Korea's Security Environment

III. Korea's National Identity and National Interests
1. Korea's National Identity

2. Korea's National Interests

IV . Korea's Key Security Issues

1. The North Korea Problem

2. The ROK-US Alliance

3. Multilateral Security Framework

V. Conclusion

- Key words : national identity, national interests, globalization, Korean Peninsula, ROK-US alliance, North-South Korean relations

【ABSTRACT】

The relative decline of the presence of the United States in the postCold War period is a significant determinant causing instability in Northeast Asia. Despite a strong US security commitment in the region, the new security circumstances may render the security condition of Korea less than stable. Given the change of security conditions related to Korea, this article examines Korea's national identity and national interests in terms of the security context. Korea has the strongest Northeast Asian identity, making regional stability the most important premise for Korea's national interest. Therefore, the security complex characteristics of the Korean Peninsula should be clearly identified in terms of Northeast Asian regional peace and stability. This article also 
shows what the specific security subjects of Korea are in the age of globalization. Closely associated with Korea's national interests, the critical security subjects of Korea are discussed for a more peaceful Korean Peninsula and more stabilized Northeast Asian region.

\section{I . Introduction}

In the post Cold War international relations, the Korean Peninsula has become not only the heart of the Northeast Asian security discourse, but also the center of global security concerns. With the end of the Cold War bipolar confrontation, scholars with perspectives mainly rooted in western tradition diagnosed that the under-development of regional institutionalization in Northeast Asia, absence of visionary leadership in the US and China, and North Korea's self-destructive survival strategy make it difficult to achieve peace on the Korean Peninsula. ${ }^{1)}$ Looking back at the last two decades of globalization, the Korean people are embarrassed by the fact that as the country has been extending its reach as a meaningful global player economically, it has struggled to contend with security issues such as the North Korean nuclear problem, revision of the ROK-US alliance, Japanese militarization, the rise of China, and so forth. Without clearly defined explanations regarding the effects of globalization on Korea's security conditions, Korea's insecurity will remain. ${ }^{2)}$

This article addresses the specific changes of Korea's security structure in the age of globalization. First, I discuss the security conditions surrounding

1) Thomas $C$ hristensen, "Fostering Stability or C reating a M onster? The Rise of China and US Policy toward East Asia," International Security 31-1 (2006), pp. 81-126; John G. I kenberry, "American $\mathrm{H}$ egemony and East Asian O rder," Australian Journal of International Affairs 58-1 (2004), pp. 353-367; T. Christensen, "China, the US-Japan Alliance, and the Security Dilemma," International Security 23-4 (1999), pp. 47-98; Arron Friedberg, "Ripe for Rivalry: Prospect for Peace in a Multipolar Asia," International Security 18-3 (1993/4), pp. 5-33.

2) When referring to "Korea," this article is generally referring to the Republic of Korea (South Korea); the D emocratic People's Republic of Korea (N orth Korea) is referred to separately. 
the Korean Peninsula both globally and regionally. The United States, despite being a non-regional actor, established its position as the most influential power balancer in East Asia, as its hegemonic role expanded into the region with a deepening regional Cold War arrangement. ${ }^{3)}$ The relative decline of the presence of the United States in the post-Cold War period, therefore, is a significant determinant causing instability in the region. Despite the strong US security commitment in the region, the new security circumstances may render the security condition of Korea less than stable. Theoretical explanations regarding the interdependent relations between the traits of globalization and its effects on Korea's security are needed. Some conceptual findings are included, such as the expanded meaning of 'security' and 'securitization.'

Second, given the change of security conditions related to Korea, this article examines Korea's national identity and national interests in terms of the security context. All nations have their own national identity. In order to understand Korea's national interest in accordance with the new security conditions in the age of globalization, Korea's national identity needs to be explained. Korea has the strongest Northeast Asian identity. This means that the regional stability of Northeast Asia is the most important premise for Korea's national interest. ${ }^{4)}$ Therefore, the security complex characteristics of the Korean Peninsula should be clearly identified in terms of Northeast Asian regional peace and stability.

Third, given the change of security conditions related to Korea, this article also shows what the specific security subjects of Korea are in the age of globalization. Focusing on ROK-DPRK relations and ROK-US relations, the critical security subjects of Korea are discussed for a more peaceful Korean Peninsula and more stabilized Northeast Asian region. The discussion also touches upon regional responses to the change of the global security environment and the development of a regional security framework.

3) Kent Calder, "U.S. Foreign Policy in N ortheast Asia," in Samuel S. Kim (ed.), The International Relations of N ortheast Asia (Lanham: Rowman \& Littlefield, 2004), pp. 225-248.

4) Ihn-hwi Park, "Sino-Japan Strategic Rivalry and the Security of the Korean Peninsula," Korean Journal of D efense Analysis 19-1 (Spring 2007), pp. 79-102; I hn-hwi Park, "D ongbuka Kukje-K wankewa H ankukeui Kukga-lik" [N ortheast Asian International Relations and Korea's N ational Interest], Kukgajeonryak [N ational Strategy] 11-3 (2005), pp. 5-32. 


\section{II . Globalization and Korea's Changing Security Environment}

\section{Globalization and Security}

The concept of security has been under serious reformation by every security referent since the Cold War ended. In the age of globalization we witnessed a general move to broaden the scope of security agenda. ${ }^{5}$ One approach was to move from a strict focus on the security of the state (national security) toward a broader or alternative focus on the security of people, either as individuals or as a global community. Security refers to guarantee or a certainty of something. Security is understood as assuring particular arrangements into the future. This usually implies stable political arrangements; social change that might upset these arrangements is then easily targeted as a threat to security. Buzan once argued that security is an essentially "contested concept," one whose meaning is flexible and the object of many competing claims and attempts at definition. ${ }^{6}$

To understand the debates surrounding so-called new threats to security, it is useful to historicize the concept. Security is a historically variable condition: while one might perhaps agree with Thomas Hobbes' claim that the fear of death is the one truly human condition, the sources of this fear vary drastically across time and space. The security of individuals can be affected in numerous ways; indeed, economic welfare, environmental concerns, cultural identity, and human rights may be germane more often than military issues. However, expanding the concept of security might be dangerous since, without a clear understanding of the nature and scope of post-Cold War security, the simplistic inclusions of other concepts and agendas can only lead to an unnecessary complication of the term. ${ }^{7)}$ Furthermore, the 'globalized

5) For general discussions on the expanded scope of security studies in the post-C old W ar era, see O le W $W_{æ v e r}$ and Barry Buzan, "After the Return to Theory: The Past, Present and Future of Security Studies," in Alan R. C ollins (ed.), Contemporary Security Studies (0 xford: Oxford U niversity Press, 2007).

6) Barry Buzan, O le W æver, and Jaap de W ilde, Security: A N ew Framework for Analysis (Boulder: Lynne Rienner, 1998), ch. 1.

7) See Stephan M. W alt, "Renaissance of Security Studies," International Studies Q uarterly 352 (1991), pp. 211-239. 
international community', in which every human being's life has become closely connected and interdependent with each other, realizes that state security has never diminished in terms of its influence on each individual's daily life.

The meaning of security after the end of the Cold War differs from region to region, and the change of security condition brought by globalization has been different based on regional political and social restrictions. Compared to Europe or the North American region, the Northeast Asian international order has experienced a distinctly unique process of formation. Unlike the European case in which countries of similar status in economic development, social stability, and at similar scientific and technological development stages, etc., formed Europe's regional security order through a process of reciprocity, the state of international relations among Northeast Asian countries could be seen as a result of the proliferation of the Western way of diplomatic relations. This kind of historical characteristic has considerably influenced the uniqueness of the regional security order as well. In Northeast Asia, there still remains the Cold-War tradition of resolving major security issues bilaterally. ${ }^{8}$ Such traditions are institutionalized in the form of a "fragmented array of bilateral relationships" "9) of which the United States is the center of these relationships.

Alongside the Cold War security tradition is an astonishing economic dynamism in Northeast Asia that is ushering in a growing regional interdependence. Because of the outcomes of globalization in the field of communication, transportation, networking, and civilian activity, distances are shrinking and the economies of the region's countries are becoming more dependent on the well-being of each other. There is also a security aspect to this new sense of regionalism: If we increasingly share a common destiny, then we will increasingly share common security concerns as well. Interdependence may reduce the risks of any serious troubles. Unfortunately, however, the development of economic interdependence does not easily bring any meaningful spillover effect into the security area.

The major limitation of Northeast Asian, or East Asian, regional security

8) Ihn-hwi Park, "Changing US Alliance Strategy and the Limits of Bilateral Alliance in N ortheast Asia," Journal of East Asian Affairs 21-1 (2007), pp. 58-60.

9) Ibid., pp. 60-62. 
seems fairly straightforward. The differences in power among different nation-states, unresolved historical issues, the existence of largely autonomous cultures unaccustomed to long-term habits of association and interaction with their neighbors, and the extraordinarily rapid economic and social change in the recent years have all constrained the development of a more mature and stabilized regional order. The Korean Peninsula, in particular, needs to pay greater attention to these factors than any other country in the region. Korea symbolizes the security confrontation of the Northeast Asian region in the age of globalization. Based on this background, it is important to figure out how to handle the ambivalence between the globalized interactions and legacy of the Cold War security complex. Whatever the solution, it should center not only on the security of Korea, but also on the new security arrangement of Northeast Asia.

\section{Changes in Korea's Security Environment}

The security environment in which Korea exists is significantly unique mainly because of the effect of globalization on security perspectives. Korea is a divided nation and neighbor to one of the most bizarre and unpredictable regimes, North Korea. Korea is also surrounded by major powers in Northeast Asia - the United States, China, Japan, and Russia. Historically, Korea has often been a victim of great power politics and rivalryparticularly between China and Japan. ${ }^{10)}$ According to one American prediction, by 2025 the international system will be a global multipolar system with gaps in national power continuing to narrow between developed and developing countries. Regarding the security conditions of the Korean Peninsula, the rise of China catches our attention. China favors maintaining a peaceful security environment in order to advance its own industrialization. Yet this rise creates dilemmas: the growing strength of China's military has alarmed its neighbors, who also depend on China for their own economic growth.

The rise of China forces Korea to ask itself two questions in terms of its own security. First, considering the changing regional security environment, it is an intricate task for a state to determine the size of national power and

10) Victor Cha, "The Security of N ortheast Asia," Pacific Focus 14-1 (2009), pp. 1-21. 
military capability required to secure its sovereignty under the assumption of anarchy in international politics. ${ }^{11)}$ States generally consider the following two questions: What kind of power distribution is recognized as safe among state actors? What efforts would each state try to pursue to secure such an order??To be more specific, the ultimate question is whether a balance of power among multiple actors or a hegemon's power maximization can obtain the desirable international security order. Whether an individual state pursues balance of power or power maximization is a result of complex foreign policy calculations that include geopolitical particularities, relations with the existing hegemon, the power distribution in international politics, and interpretation of one's own opportunities to expand one's power. ${ }^{12)}$ The consideration of such elements in Northeast Asia can be observed in the relationship among the United States, China, and Japan and each state's status in the region. The United States is a regional stabilizer of geographical distance. Its security alliance with Japan has been strengthened and transformed to suit the twenty-first century international security environment. ${ }^{13)}$ Maritime territorial disputes continue to occur between China and Japan - needless to mention historical and territorial disputes involving other actors. Considering the circumstantial evidence, the regional actors are more likely to pursue a balance of power approach.

The second question is more specifically associated with the current debate on the new international order based on the "G2." ${ }^{14)}$ There are contending arguments on continuity and disparity between global and regional hegemonic influence. According to offensive realists, meaningful global hegemony cannot exist without clear superiority in military capability. ${ }^{15)}$ All hegemonic influence in theory, then, is limited to the regional level. If we

11) Kenneth W altz, Theory of International Politics (N ew York: M cG raw-H ill, 1979), ch. 6; Thomas Christensen (1999), op. cit., pp. 51-53.

12) Robert Gilpin, War and Change in World Politics (Cambridge: Cambridge U niversity Press, 1983), ch. 5.

13) Christopher W. H ughes and Akiko Fukushima, "U .S.-Japan Security Relations-T oward Bilateralism Plus," in Ellis S. Krauss and T. J. Pempel (eds.), Beyond Bilateralism: U.S.Japan Relations in the N ew Asia-Pacific (Stanford: Stanford U niversity Press, 2004).

14) G2 refers to "Group of Two," a proposed informal special relationship between the United States and China.

15) John M earsheimer, T he T ragedy of G reat Power Politics (N ew York: W. W. N orton, 2001), p. 145. 
apply this perspective to the G2 global leadership between the United States and China, the Northeast Asian regional security could fall under Chinese regional hegemonic influence instead of under American global comprehensive influence. Different analytical perspectives, in contrast, explain that in the contemporary world of globalization, development of information technology, and prevalence of institutionalization, the influence of global and regional hegemony may not be distinctively defined. ${ }^{16)}$ Therefore, within both the global level and the regional level, because of the United States, any pursuit of hegemony by China or Japan remains very limited. In terms of the G2, the United States will continue her global leadership even within the Northeast Asian space, and on symbolic subjects the United States will ask for a harmonious partnership with China to maintain a more efficient leadership.

Regarding Korea's security and the rise of China and the US-China relationship, it is useful to think about the historical change of the Northeast Asian security structure. This is because the change of Sino-US power relations has centered on the developmental changes of the Northeast Asian security arrangements. The beginning of the Cold War in the Northeast Asian region, marked by the US "Reverse Course," was the beginning of the socalled first stage of Northeast Asian international relations. ${ }^{17)}$ The bilateral alliance structure applied to Korea, Japan, Taiwan, and a number of Southeast Asian countries was significant in that it completely excluded and isolated China ${ }^{18)}$ In the mid-1960s, the Cold War structure in the Northeast Asian region was finalized with the normalization of the relationship between South Korea and Japan. The first stage of Northeast Asian international relations met its turning point in 1969 with President Richard Nixon's Guam Doctrine. More specifically, the Northeast Asian international relations underwent structural change in 1972 when China and Japan normalized relations.

16) Spike V. Peterson, "Shifting Ground: Epistemological and Territorial Remapping in the Context of G lobalization," in Eleonore Kofman and Gillian Youngs (eds.), Globalization: Theory and Practice (London: Pinter, 1998), pp. 11-27; Simon D alby, "Crossing D isciplinary Boundaries: Political Geography and International Relations after the Cold War," in Eleonore Kofman and Gillian Youngs, Globalization: Theory and Practice (London: Pinter, 1998), pp. 29-41.

17) Thomas Christensen, U seful Adversaries: Grand Strategy, D omestic M obilization, and SinoAmerican Conflict, 1947-1958 (Princeton: Princeton U niversity Press, 1996), ch. 5.

18) I bid., pp. 181-93. 
Although it cannot be said that Northeast Asian relations went through a complete change due to the sharp Cold War order on the Korean Peninsula, the amelioration of US-China relations and normalization of Japan-China relations showed a definite contrast to the first stage which was characterized by China's isolation. ${ }^{19)}$ The second stage of Northeast Asian international relations ended with the end of the Cold War, ushering in the third stage at around 1990. With the end of the Cold War, China has begun to play an active role in international society, in particular having improved relations with Korea. US-China-Japan relations entered a new phase in this third stage. However, in these actors traditional security relations there has been no development of mutual trust.

Preparing for the full-scale rise of China, the beginning of the G2 accelerates the new stage of international relations in Northeast Asia. Most importantly, Northeast Asian security structure is still characterized as a coexistence of strategic conflict and realistic cooperation (as we experienced during the military tension between the ROK-US alliance and China-DPRK cooperation after the Cheonan incident in 2010). As a relatively weaker country, it is difficult for South Korea to change the framework of Northeast Asia's security structure. However, because the conflict between the United States and China has not yet intensified radically, now would be an appropriate time to maximize South Korea's national interest, including issues concerning North Korea.

Lastly, the most salient and enduring security subject in the Northeast Asian region remains how to handle North Korea. The past twenty years of globalization shows that the North Korean regime continues to pursue a nuclear weapons program. Offers by the United States to North Korea for its disarmament cannot credibly reduce the regime's fear for its survival. Both the United States and international community have moved between engagement and coercion in dealing with North Korea, leading to occasionally contradictory policies and a lack of consistency on the part of both the United States and North Korea. The North Korea problem is most symbolic and significant among any other Northeast Asian regional security

19) M ichael Schaller, "D etente and the Strategic Triangle: Or, 'D rinking Your $M$ ao Tai and $\mathrm{H}$ aving Your Vodka, T 0o'," in Robert S. Ross and Jiang Changbin (eds.), Reexamining the Cold War: U S-China Diplomacy 1954-1973 (Cambridge: H arvard University Press, 2001), pp. 361-392. 
issue, since the North Korea's resistance to cooperatively participate in the Northeast Asian regional order has brought about many of the regional security difficulties such as the US-China conflict over the Korean Peninsula, the underdevelopment of multilateralism in the region, arms race among Northeast Asian countries, and so forth.

\section{Korea's National Identity and National Interests}

\section{Korea's National Identity}

Korea's national identity and interests are the outcomes of the connection between both the global and regional security environments of Korea and specific security issues to deal with the survival of Korea within those security environments.

All nations have their own national identity. To explain Korea's national interest in accordance with the prospects of Sino-US relations, there needs to be an explanation about Korea's national identity. For the most part, two characteristics stand out. The most prominent is Korea's identity as a 'Northeast Asian state.' We oftentimes speak of the 'Northeast Asian region', but it is difficult to pin point a certain country as a Northeast Asian state. For instance, China, Japan, Russia, as well as the United States each has its own Northeast Asian interest; but in terms of national identity, it is impossible to prescribe these countries as solely Northeast Asian countries.

From this point of view Korea is the country that has the strongest Northeast Asian identity. Such explanation means that the regional stability of Northeast Asia is the most important premise for Korea's national interest. The problem, however, is that from the beginning of the twenty-first century, Northeast Asia has taken center stage in international politics, for it is in this region where political, economic, and security issues collide most severely among the great powers. However, this situation requires that Korea have the diplomatic power to both continuously and effectively play at the regional and global levels instead of just stagnating at the regional level.

Northeast Asia is a contact point of continental powers and maritime powers where China, Russia, Japan and the United States clash and coexist at the same time. Moreover, Northeast Asia is one of the Eurasian continent's 
main strategic points and a rare place where the world's four superpowers geographically, politically, economically, and culturally intersect. Since the Korean Peninsula is positioned at the center of such an area, the stability and balance of Northeast Asia becomes a life and death precondition for Korea's national interest and security.

The second main characteristic of Korea's national identity is the security complex of the Korean Peninsula. As one can see from the current North Korea problem, it is impossible to guarantee Korea's security and national interest without balance and harmony between the 'peninsular factors' and the 'international factors' because the two categories of factors are intricately intertwined. As a result, Korea has to face the fact that the Korean Peninsula's peace and security cannot be solved from a peninsular perspective or international perspective only. Neighboring great powers such as China, Japan, and the United States each has their own interests on the peninsula. A future unified government on the Korean Peninsula to be under any one particular country's exclusive influence is something each actor wants to avoid. Accordingly, Korea's security strategy must be very intricately established via a harmonious combination of the 'peninsular' and 'international' factors.

The United States and China are the two key actors of Northeast Asia, and they pursue their own advantages on the peninsula. If conflict were to occur in Sino-US relations or the Sino-US/Japan alliance relations, we know from history that it will be most likely expressed on the Korean Peninsula. Consequently, Korea will always have to have the ability to strategically analyze how the power structure between the United States and China changes, and how that change interferes with the Korean Peninsula.

\section{Korea's National Interests}

Based on the national identity analyzed above, the following explanations prescribe Korea's national interest.

First, at the peninsular level, Korea's national interest is to achieve a consolidation of democracy, continue to further its economic growth, and, on top of this, propel cultural pluralism. According to Korea's constitution, Korea' Øs key national interests include security and prosperity of the Korean nation; promotion of democracy, freedom, and human dignity; contribution to 
world peace; and achievement of peaceful unification. A future unified North-South Korean government will have to exist on the premise of realizing such national interests. In particular, Korea's political democratization has developed beyond the level of any other democracy in East Asia. Korea's experience thus should become the model for East Asia.

The greater the relative power of the states surrounding the Korean Peninsula, the more one must focus on universal principles of international society such as democracy, free market economy, and multiculturalism. As Korea lags behind China and Japan in terms of physical power (such as military or economic power), and as North Korea continues to pursue an irrational diplomatic strategy by defying the international community, Korea must establish a democracy and a market economy to a level that can be respected by international society. Only through such efforts will Korea be able to maintain its integrity at the peninsular level and guarantee a relative superiority above neighboring states. ${ }^{20)}$ For instance, Korea's democratization occurred voluntarily as a result of industrialization and the expansion of civil society. This is something Korea must be proud of when compared to China, a socialist state, or Japan, where a single party has been monopolizing power. In addition, as the North Korean nuclear crisis continues, making it difficult for a peaceful relationship to be nurtured between the DPRK and ROK, Korea must try even harder to clearly build the identity of a future unified Korea. From this perspective, Korea's national interest at a peninsular level carries significant meaning.

Second, Korea's national interest at the regional level is to acquire a certain degree of deterrence capability so that states surrounding the Korean Peninsula cannot infringe upon Korea's sovereignty. Korea must also take the initiative to develop 'institutionalized security framework' in the region, and also develop diplomatic strategy and means so that the great powers can balance each other in their own sense. ${ }^{21)}$ In order to secure such interests at the regional level, Korea must implement diplomatic strategies and means which take into consideration its national capacity. In particular, increasing the

20) Sang-hyun Lee, "N ational Security Strategy of the Lee M yung-Bak Government: The Vision of 'Global Korea' and Its Challenges," The Korean Journal of Security Affairs 14-2 (2009).

21) Sang-H yun Lee, "RO K-U S Relations in Lee M yung-bak Government: T oward a Vision of a 21st Century Strategic Alliance," J ournal of East Asian Affairs 22-1(2008). 
institutionalization of diplomatic relations in Northeast Asia is a very important task for Korea's national interest. Compared to the level of institutionalization in Europe, institutionalization in East Asia is underdeveloped. However, compared with China and Japan, Korea is in an advantageous position to lead regional institutionalization, as the historical animosity between China and Japan makes Korea better suited to play the role of diplomatic mediator.

In terms of regional interest, the Korea-US alliance still remains a valuable diplomatic asset. If in case the conflict between China and Japan becomes severe - even to the level of military conflict_Korea can request the help of a non-regional superpower, the United States. As well, in pre-modern times, Korea and China had maintained an alliance relationship for thousands of years, and such alliance was formed on the basis of unequal relations between the two countries. Also, in terms of the diplomatic relationship with Japan, Japan has attempted to invade Korea's territory, and even to gain imperialistic control over the peninsula. Thus, utilizing the capacity of a superpower which does not have a territorial interest in the peninsula to diplomatically deal with China and Japan, and at the same time, seeking institutional stability in the region are very important to Korea's national interest.

Third, at a global level, Korea's national interest is to connect universal values (such as democracy, freedom, fair competition, human rights, etc.) to its national interest, to preserve access to the most advanced capitalist areas (represented by the United States and Western Europe), and to inaugurate a national image that contributes to world peace. In particular, Korea's Northeast Asian identity requires it continue to be mindful of the need for balanced diplomatic strategies - a balance between the regional level and beyond. In other words, as Korea's national identity defines it as a Northeast Asian state, rather than confining itself within the borders of the region, developing amicable diplomatic relations with superpowers outside of the region is essential. It is also crucial to pursue universal and not simply regional interests.

Militarily, Korea should dispatch peacekeeping troops to conflict areas, work to free itself from its current image as a separated country, and likewise assume a positive image as a contributor to world peace. Economically, by expanding various levels of economic exchanges, Korea must learn and apply a developed economic system, scientific technology, and developed economic 
strategies. Culturally, it must show that Korean cultural aspects can be endorsed globally by creating a means of cultural diplomacy more expansive than the current Korean Wave (i.e., Hallyu). Lastly, official development assistance (ODA), which the Korean government has been giving a lot of lately, is a desirable national strategy. Korea is a prime example of a country which received international support and was able to transform itself into a strong economic power. Thus, by assuming this into its own national diplomatic strategy, Korea must create a national image of itself as a positive contributor to international peace.

\section{Korea's Key Security Issues}

Korea needs to think of security in terms of its 'Northeast Asian identity' and national security interests. Therefore, Korea must strategically manage key security issues in accordance with global and regional security environments. In this section, the issues of the North Korea problem, the ROK-US alliance, and the building of a regional multilateral security framework shall be discussed.

\section{The North Korea Problem}

The North Korean nuclear program remains the most critical security issue both at the peninsular and regional levels. North Korea's choice of 'nuclear diplomacy' as its regime survival strategy concurrently transformed international security concerns of the United States, China, and Japan because of their inevitable strategic engagement. ${ }^{22)}$ Therefore, whether achieved forcibly or amiably, negotiations not only between North and South Korea, but also between the United States and China, or between China and Japan, are critical preconditions in solving the North Korea problem. The involvement of Northeast Asian states in the North Korean nuclear issue proves the characteristic features of Korea's national identity and interests as explained above.

22) Joel S. W it, "Enhancing US Engagement with N orth Korea," The Washington Quarterly 30-2 (2007), pp. 53-71. 
Interestingly, North Korea emphasizes two facts. One is that no nuclear capability, substance, or equipment has left the Korean Peninsula. The other is that denuclearization of the Korean Peninsula was the dying wish of its former leader Kim Il-sung. In other words, North Korea is, on its own, trying to soft-pedal the significance of its nuclear program to the Northeast Asian region. North Korea is aware that the moment that its nuclear diplomacy exceeds the Northeast Asian region, it will be prone to severe criticism from the international society, which will jeopardize the survival of the incumbent regime. In short, in character, the North Korean nuclear issue is highly a security concern of Northeast Asia, and it deeply involves the national interests of the United States, China, and Japan.

The precarious situation inside North Korea (i.e., the death of the DPRK leader Kim Jong-il and the succession of the DPRK leadership to his third son Kim Jung-eun) makes the South Korean government's handling of the North Korea crisis more stressful. Despite the situation, however, the underlying issues remain depressingly the same: how to reign in North Korea's nuclear programs and entice the DPRK to open its markets and borders. ${ }^{23)}$ The basic choice of strategies confronting countries is also the same: negotiate or confront.

In the same vein, it is strategically important to identify that the North Korean nuclear issue is different in one aspect from many of the other international security crises. Unlike in the cases of Iran or Iraq-or that of other rogue regimes, for that matter-the United States has agreed multiple times on the basic outlines for resolution of the North Korean nuclear problem. The basic agreement was first laid out in the 1994 Geneva Agreed Framework and later reiterated in the 19 September 2005 Joint Statement and once again in the 13 February 2007 agreement (on the initial actions for the implementation of the joint statement). All of the documents on those agreements contain the core aspects of the deal: North Korea gives up its nuclear weapons program, and the United States will normalize relations with North Korea and develop further diplomatic and economic relations with the DPRK. Unfortunately, while trying to figure out how to implement the agreement, the two sides have shown serious mistrust.

23) D avid Kang, "Between Balancing and Bandwagoning: South Korea's Response to China," Journal of East Asian Studies 9-1 (2009), pp. 8-10. 
Despite the concern of South Korea and the international community, North Korea twice conducted nuclear tests including an underground nuclear explosion on May 25, 2009, and also test-fired several ground-to-air and ground-to-ship ballistic missiles. The North Korean nuclear problem has lasted for almost two decades, filling the pages of Northeast Asia's post-Cold War stories on security. Living under this nuclear threat has become a part of daily life for many South Koreans. As the problem continues to go unresolved, more of the general public and policymakers in South Korea and the United States are beginning to reach the pessimistic idea that North Korea might never give up its reckless pursuit of becoming a nuclear state.

Such pessimism makes the so-called 'South-South conflict' in Korea more unmanageable, placing South Koreans into one of two different camps: the pro-engagement camp that favors engaging North Korea to bring about gradual reform and openness in the DPRK; and the pro-regime change camp, which advocates regime change in North Korea to completely stop Pyongyang's irrational behavior. Kim Jong-il might have believed that pursuing nuclear weapons is North Korea's only option for defending itself against security threats and for avoiding any loss of control over domestic politics. If the DPRK is indeed determined to be a nuclear state, then there is not much the international community can do.

In a sense, the international community may simply sit and wait until North Korea shows the world their nuclear weapons, and try to trade them for an appropriate price. To avoid such a worst case scenario, there are two options. First, it is extremely important that both Seoul and Washington share the goal of complete denuclearization of North Korea. Since the Barack Obama administration came to power in the United States, however, there have been several indications that the United States may accept North Korea as a de facto nuclear power under the condition that Pyongyang does not attempt to proliferate. ${ }^{24)}$ Although this indication may not reflect the US government's official position, many Koreans are worried that Washington may compromise and complete a nuclear deal with Pyongyang due to other US security priorities.

24) For example, the former US Secretary of D efense Robert Gates mentioned in an article published in Foreign Affairs in 2009 that "N orth Korea has built several bombs." See, Robert Gates, "A Balanced Strategy," Foreign Affairs (J anuary/February 2009). 
Second, the role of China is critical in the negotiation process of the North Korean nuclear problem since China has the most leverage over North Korea. Due to the nuclear problem, both South Korea and China have been caught between the United States and North Korea. China has continued to emphasize economic relations with the DPRK over the years, although there has been intense debate within China about the best way to deal with North Korea. Considering the inseparable relations between the countries, China must participate more actively in the international community to deal with the denuclearization of North Korea.

\section{The ROK-US Alliance}

Historically, whenever there was a major political change in the Northeast Asian region, Korea's destiny was always at a critical point. ${ }^{25)}$ This historical truth has not changed in the pre-modern era or even after the development of the international relationships in Northeast Asia in the modern era. History is unlikely to repeat itself, as the reality of post-modern international relations of the twenty-first century is very different from past international relations for any of the Northeast Asian countries to resort to military conflict. However, the region is still under a hostile diplomatic environment due to historical and territorial disputes and intensive arms race.

Under such circumstances, it is strategically easy to comprehend why Korea has the United States, a global hegemonic state outside the Northeast Asian region, as its alliance partner. The Korea-US alliance is almost 60 years old. The United States traditionally interacted with East Asia through a series of bilateral arrangements, known as the 'hub and spokes' model. Compared to the unique diplomatic alliance Korea had with China for thousands of years, the history of the Korea-US alliance is incomparably short; however the fact that Korea's alliance partner is not a Northeast Asian country is a positive point. Unless Korea independently had become a strong state after establishing its government in 1948 (sans any alliances), an alliance with China or Japan would not have been as beneficial as the current ROK-US alliance, nor would such an alliance have been viewed as one of equal

25) Gerald H ensley, "Asia-Pacific Security: Paradox and Riddle," N ew Zealand International Review 23-1 (2007), pp. 33-37. 
powers. More than anything, the Korea-US alliance is a valuable diplomatic asset because it allows Korea to pursue its national interests separately on the Northeast Asian level and on the global level. ${ }^{26)}$

The problem is under what rationale the ROK-US alliance should continue in the future. At their first summit meeting, presidents Lee Myung-bak and Barack Obama adopted "the joint vision for the ROK-US alliance," which calls for building a broader, twenty-first century strategic partnership in the realms of politics, the economy, culture and other areas beyond the security arena. As far as Korea's national security interests are concerned, the ROKUS alliance takes the highest priority in South Korea's national security strategy. The future international order has been characterized as a complex network or complex transformation. In such an environment, a country like South Korea, surrounded by stronger neighbors, must pursue a national strategy that exploits the benefits of rich, diverse, and complex networks in all areas of national security. In that sense, the relationship with the United States takes the top priority.

Even during the stormy years of the Kim Dae-jung and Roh Moo-hyun administrations, the ROK-US alliance survived and was even strengthened and reconfigured in an ambitious way: South Korea sent more troops to Iraq than any country other than the United States and Britain; the ROK and US militaries have adjusted to a major reconfiguration of the US military deployments in South Korea; and the two countries have signed and ratified a bilateral free trade agreement. The key issue confronting the alliance today is the strategic dissonance regarding North Korea, but there are other challenges that face the alliance: the rise of China, threats to international order posed by terrorists, and proliferation of weapons of mass destruction, as well as the need to restructure the alliance to meet changing international and domestic realities in both countries.

From Korea's perspective the relationship with China is less important than ROK-US relations. For the future of a more prosperous and stabilized Northeast Asia, Korea, China, and the United States must find common ground to better understand each other's intentions in a constructive way. In

26) Sang-hyun Lee and Jong-chun Baek, Korea-U .S. Relations in Transition: Korea-U.S. Alliance in Retrospect and Prospects for a N ew Strategic Partnership (Seongnam, Korea: Sejong Institute, 2002). 
particular, both Korea the United States must work to reduce the negative connotations associated with the term 'strategic alliance.' Many Chinese understand the concept of 'value-based partnership' as intended to exclude countries with different values, particularly China. The ROK-US alliance does not aim to prevent a rising China; rather, it intends to cope with comprehensive security threats of the international community in the future.

\section{Multilateral Security Framework}

Scholars both from East Asian and Western countries have offered many explanations for the underdevelopment of regional institutions in East Asia. For example, East Asia comprised a land and a maritime theater with no clear dividing line between East and West. ${ }^{27)}$ Unlike in Western Europe, the United States lacked allies in East Asia both during and immediately after World War II. The United States faced less-than-ideal conditions for forming a collective defense coalition in Asia. In addition, the region's deep distrust of Japan argued against reintegrating the former adversary in a region-wide coalition. ${ }^{28)}$ Some who prefer to explain the East Asian regionalism from an East Asian perspective often refer to former-East Asian leaders such as Rhee Syngman or Yoshida Shigeru and those leaders' strong attachment to be part of the American security architecture by utilizing an anti-communist sentiment for their domestic politics. ${ }^{29)}$

Handling East Asian security issues in terms of the regional context has been carefully considered since the end of the Cold War. Compared to European regionalism, in particular, we can consider two major reasons behind the underdevelopment of East Asian regionalism. First, the European nation-state and the Asian nation-state are at different stages of evolution: the European state is increasingly characterized by an erosion of sovereignty, growing economic interdependence, and sustaining of internal power by increasing external cooperation. The progressive erosion of national

27) Paul Bracken, Fire in the East: The Rise of Asian M ilitary Power and the Second N uclear Age (N ew York: H arper Collins, 1999), p. 26.

28) Gerrit W. Gong (ed.), M emory and H istory in East and Southeast Asia (W ashington, D.C.: Center for Strategic and International Studies, 2001).

29) Samuel Kim, International Relations of N ortheast Asia (N ew York: Rowman \& Littlefield, 2004). 
sovereignty in Europe is the result of two tendencies: the voluntary transfer of sovereignty to international or supranational institutions to resolve outstanding conflicts between states. ${ }^{30}$ With the exceptions of Australia, New Zealand, and Japan, the domestication of international politics has not progressed very far in the region.

Second, the low level of institutionalized cooperation in the region is the absence of an emergent collective identity in East Asia, a factor that bears directly on the debate generated by Alexander Wendt. Wendt argues that one solution to the problem of collective action - which is a motor propelling the institutionalized cooperation in the European security space - is located in the process of collective identity formation which has arguably occurred in Europe and is at an embryonic state in Asia. ${ }^{31)}$ In Europe there is an increasing identification of the self-interest of the nation-state with the collective interest of Europe. According to Wendt, three variables can be identified: structural contexts, systemic processes, and strategic practice. These factors promote collective identity formation and provide an important foundation for multilateral institutions by increasing the willingness to act on generalized principles of conduct and diffuse reciprocity.

More importantly, Northeast Asia has survived without any permanent multilateral security mechanism. The region apparently lacks a more or less enduring multilateral mechanism like the Organization for Security and Cooperation in Europe (OSCE). However, people in the region view the emergence of linkages in East Asian regionalism as being beneath the level of state actions. East Asian countries have in recent years become considerably more independent, connected, and cohesive. This increased cohesiveness has been driven by developments, among other things, in trade and investment, cross-border production, banking, technology sharing, popular culture, transportation, communication, and environmental cooperation, as well as in crime, drug, and disease control. Previous South Korean governments all endeavored to contribute to create more or less lasting multilateral security arrangements in Northeast Asia. The Kim Young-sam government proposed to create a Northeast Asia Security Dialogue (NEASED) at the first ASEAN

30) The typical example for this case is that the European Coal and Steel Community was the first step toward mollifying the historic enmity between France and Germany.

31) See Alexander W endt, "Collective Identity Formation and the International State," American Political Science Review 88-2 (1994), pp. 384-396. 
Regional Forum Senior Official's Meeting. ${ }^{32)}$ The Kim Dae-jung administration emphasized the importance of multilateral security cooperation in Northeast Asia on many occasions. There is a long and hard way to accomplish such a mechanism in the region. However, in order for these efforts to succeed, there must be a region-wide consensus on the ideas, interests, and institutions for multilateral security framework.

Considering Korea's national identity and national interest, stable multilateral diplomatic relations of Northeast Asia is one of the most critical conditions of Korea's security. Within a similar vein, regional multilateral framework should be supported by the development of the collective identity among 'Northeast Asians.' To advance the sense of Northeast Asian collective identity, systemic processes, which refer to the dynamics in the external context of state action, are important. Countries in the region differ in their domestic values on many security issues such as Japan's military buildup, China's rising naval power, North Korea's nuclear program, and the US-centric bilateral alliance system. Different domestic security values among Northeast Asian countries on these subjects are known as the most significant barriers to the emergence of a sense of collective identity. The systemic process should move forward interdependence and convergence of each state's domestic values. We may consider a creation of multilateral security dialogue, region-wide collective military exercises, and civilian discussion channels on Northeast Asian military issues as the specific conduct of such systemic processes.

\section{Conclusion}

Looking retrospectively at Korea's national development since the establishment of the Republic of Korea in 1948, national security was seen as particularly crucial in the country's early years. Korea was the weakest nation in the Northeast Asian region. However, today Korea is being categorized as a "middle power" that can assume initiative in international matters that are too sensitive or impossible for stronger states to engage in. ${ }^{33)}$ Moreover,

32) Sang-hyun Lee, op. cit., pp. 24-25.

33) Eduard Jordan, "The Concept of a M iddle Power in International Relations: Distinguishing between Emerging and Traditional M iddle Powers," Politikon 30-2 (2003), pp. 99-104. 
compared to any of its neighbors, Korea has achieved a dynamic and participatory democracy. Due to such democracy, Korea has experienced amazingly rapid development and developed a highly professional civil society. Furthermore, compared to other regions, Northeast Asia's collective sense of regional identity is underdeveloped. For many reasons, Korea is at a contact point of continental powers and maritime powers and thus is relatively better situated to develop the collective identity of the Northeast Asian region.

Regarding the security concerns of Korea, it is highly probable that the United States, China, and Japan will adhere to policies of maintaining the status-quo of the North-South Korean division. If the North Korean nuclear problem is not resolved smoothly, such probability will increase. ${ }^{34)}$ To remain as a meaningful actor in Northeast Asia is not an easy task. The Korean Peninsula is a place of strategic importance, where territorial and marine forces collide and western and non-western civilizations border. Thus, there should be consistent emphasis that, without peace and prosperity on the peninsula, Northeast Asian regional security cannot be guaranteed. After the end of World War II, Northeast Asian international relations developed a complex security structure that depends on competing elements: the role of the United States as a balancer, the possibility of hegemonic war between China and the United States, the US-Japan alliance overcoming cultural differences, and finding resolutions to the division of the Korean Peninsula and the Taiwan Strait issue. The course of history has a definite meaning. Considering the change of power balance among the surrounding states, continuous attention must be paid to Korea's national interests.

\section{REFERENCES}

Buzan, Barry and Gerald Segal. "Rethinking East Asian Security." Survival 36-2 (1994), pp. 3-21.

Buzan, Barry and Lene Hansen. The Evolution of International Security Studies. Cambridge: Cambridge University Press, 2009.

34) Presidential Committee on $\mathrm{N}$ ortheast Asian Cooperation Initiative, "Analysis on N eighboring Four Countries' M id-term Security Strategy" (1 April 2005). 
Buzan, Barry, Ole Wæver and Jaap de Wilde. Security: A New Framework for Analysis. Boulder: Lynne Rienner, 1998.

Calder, Kent. "U.S. Foreign Policy in Northeast Asia." In Samuel S. Kim. ed. The International Relations of Northeast Asia. Lanham: Rowman \& Littlefield, 2004.

Cha, Victor. "The Security of Northeast Asia." Pacific Focus 14-1 (2009), pp. 1-21.

Christensen, Thomas J. "China, the US-Japan Alliance, and the Security Dilemma." International Security 23-4 (1999), pp. 47-98.

. "Fostering Stability or Creating Monster?: The Rise of China and U.S. Policy toward East Asia." International Security 31-1 (2006), pp. 81-126.

. Useful Adversaries: Grand Strategy, Domestic Mobilization, and Sino-American Conflict 1947-1958. Princeton: Princeton University Press, 1996.

Dalby, Simon. "Crossing Disciplinary Boundaries: Political Geography and International Relations after the Cold War." In Eleonore Kofman and Gillian Youngs. eds. Globalization: Theory and Practice. London: Pinter, 1998.

Duffield, John S. "Asia-Pacific Security Institutions in Comparative Perspective." In G. John Ikenberry and Michael Mastanduno. eds. International Relations Theory and the Asia-Pacific. New York: Columbia University Press, 2003.

Friedberg, Arron. "Ripe for Rivalry: Prospect for Peace in a Multipolar Asia." International Security 18-3 (1993/4), pp. 5-33.

Gates, Robert. “A Balanced Strategy." Foreign Affairs (January/February 2009).

Gilpin, Robert. War and Change in World Politics. Cambridge: Cambridge University Press, 1983.

Hensley, Gerald. "Asia-Pacific Security: Paradox and Riddle." New Zealand International Review 23-1 (1998), pp. 33-37.

Hughes, Christopher W. and Akiko Fukushima. "U.S.-Japan Security Relations - Toward Bilateralism Plus." In Ellis S. Krauss and T. J. Pempel. eds. Beyond Bilateralism: U.S.-Japan Relations in the New Asia-Pacific. Stanford: Stanford University Press, 2004.

Ikenberry, G. John. "American Hegemony and East Asian Order." Australian Journal of International Affairs 58-1 (2004), pp. 353-367.

Jordan, Eduard. "The Concept of a Middle Power in International Relations: Distinguishing between Emerging and Traditional Middle Powers." Politickon 30-2 (2003), pp. 99-104. 
Kang, David. "Between Balancing and Bandwagoning: South Korea's Response to China." Journal of East Asian Studies 9-1 (2009), pp. 1-28.

Khong, Yuen Foong. "The United States and East Asia: Challenges to the Balance of Power.” In Ngaire Woods. ed. Explaining International Relations since 1945. Oxford: Oxford University Press, 1996.

Kim, Samuel. International Relations of Northeast Asia. New York: Rowman \& Littlefield, 2004.

Lee, Sang-Hyun. "National Security Strategy of the Lee Myung-Bak Government: The Vision of 'Global Korea' and Its Challenges." The Korean Journal of Security Affairs 14-2 (2009).

- "ROK-US Relations in Lee Myung-bak Government: Toward a Vision of a 21st Century Strategic Alliance." Journal of East Asian Affairs 22-1 (2008).

Lee, Sang-Hyun and Jong-Chun Baek. eds. Korea-U.S. Relations in Transition: Korea-U.S. Alliance in Retrospect and Prospects for a New Strategic Partnership. Seongnam, Korea: Sejong Institute, 2002.

Lind, Jennifer M. "Pacifism or Passing the Buck." International Security 29-1 (2004), pp. 92-121.

Mearsheimer, John. "Back to the Future: Instability in Europe after the Cold War." International Security 15-1 (1990), pp. 5-56.

. The Tragedy of Great Power Politics. New York: W. W. Norton, 2001.

Mochizuki, Mike M. "Terms of Engagement: The US-Japan Alliance and the Rise of China." In Ellis S. Krauss and T. J. Pempel. eds. Beyond Bilateralism: U.S.-Japan Relations in the New Asia-Pacific. Stanford: Stanford University Press, 2004.

Park, Ihn-hwi. "Changing U.S. Alliance Strategy and the Limits of the Bilateral Alliance Structure in Northeast Asia." Journal of Northeast Asian Affairs 21-1 (2007), pp. 49-92.

. "Dongbuka Kukje-Kwankewa Hankukeui Kukga-Iik" [Northeast Asian International Relations and Korea's National Interest]. Kukgajeonryak [National Strategy] 11-3 (2005), pp. 5-32. . "Sino-Japan Strategic Rivalry and the Security of the Korean Peninsula.” Korean Journal of Defense Analysis 19-1 (2007), pp. 79-102.

Peterson, Spike V. "Shifting Ground: Epistemological and Territorial Remapping in the Context of Globalization." In Eleonore Kofman and Gillian Youngs. eds. Globalization: Theory and Practice. London: Pinter, 1998. 
Presidential Committee of ROK. "Analysis on Neighboring Four Countries' Mid-term Security Strategy.” 1 April 2005.

Schaller, Michael. "Detente and the Strategic Triangle: Or, 'Drinking Your Mao Tai and Having Your Vodka, Too'." In Robert S. Ross and Jiang Changbin. eds. Re-examing the Cold War: US-China Diplomacy 1954-1973. Cambridge: Harvard University Press, 2001.

Snyder, Glenn H. "Mearsheimer's World-Offensive Realism and the Struggle for Security: A Review Essay." International Security 27-1 (2002), pp. 149-173.

Solingen, Etel. "East Asian Regional Institution: Characteristics, Sources, Distinctiveness." In T. J. Pempel. ed. Remapping East Asia: The Construction of a Region. Ithaca: Cornell University Press, 2005.

Walt, Stephen M. "The Renaissance of Security Studies." International Studies Quarterly 35-2 (1991), pp. 211-239.

Waltz, Kenneth N. "The Origin of War in Neorealist Theory." In Robert I. Rotberg and Theodore K. Rabb. eds. The Origin and Prevention of Major Wars. New York: Cambridge University Press, 1989.

. Theory of International Politics. New York: McGraw-Hill, 1979.

Wæver, Ole and Barry Buzan. "After the Return to Theory: The Past, Present and Future of Security Studies." In Alan R. Collins. ed. Contemporary Security Studies. Oxford: Oxford University Press, 2007.

Wendt, Alexander. "Collective Identity Formation and the International State." American Political Science Review 88-2 (1994), pp. 384-396.

Wit, Joel S. "Enhancing US Engagement with North Korea." The Washington Quarterly 30-2 (2007), pp. 53-71. 